\section{Pear Responses to Split Fertigation and Band Placement of Nitrogen and Phosphorus}

\author{
Xinhua Yin ${ }^{1,4}$, Jinhe $\mathrm{Bai}^{2}$, and Clark F. Seavert ${ }^{3}$
}

ADDITIONAL INDEX WORDs. leaf nutrition, yield, quality, superficial scald, soil nutrient level

SUMMARY. Single broadcast application of nitrogen $(\mathrm{N})$ and phosphorus $(\mathrm{P})$ on the soil surface results in low use efficiency of applied $\mathrm{N}$ and $\mathrm{P}$ in pear (Pyrus communis) production systems in Oregon and the Pacific northwestern United States. A field experiment was conducted from 2005 through 2006 to evaluate the effects of split fertigation and band placement as alternate $\mathrm{N}$ and $\mathrm{P}$ management practices in 'Anjou' pears growing on a Parkdale loam soil near Parkdale, OR. Measurement and analysis of tree nutrition, fruit yield, quality, and storability, as well as indigenous soil nutrient supply was the scope of the experiment. To evaluate fertilizer management practices on pear growth and productivity, the following four treatments were tested with a randomized complete block design replicated four times: 1) broadcast application of $\mathrm{N}$ and $\mathrm{P}$ on the soil surface in a 10 - $\mathrm{ft}$-wide, weed-free strip centered on the tree row, 2) band placement of $\mathrm{N}$ and $\mathrm{P}$ on both sides of tree rows in $1 \times 1$ - $\mathrm{ft}$ ditches (width $\times$ depth), 3 ) $1 \times 1$-ft ditches were dug using the band placement equipment, the dug soil was completed returned to the ditch without any fertilizer, and the broadcast application of $\mathrm{N}$ and $\mathrm{P}$ on the soil surface was applied on a 10-ft-wide, weed-free strip centered on the tree row, and 4) fertigation of $\mathrm{N}$ and $\mathrm{P}$ split into five equal applications throughout the growing season. Nitrogen and $P$ fertilizers were applied to treatments 1,2 , and 3 at $100 \mathrm{lb} /$ acre $N$ and $55 \mathrm{lb} /$ acre $P$, while treatment 4 received only $80 \mathrm{lb} /$ acre $N$ and $44 \mathrm{lb} /$ acre $P$. The 2 -year average results show leaf $\mathrm{N}$ and $\mathrm{P}$ concentrations in the fall were increased by $10.0 \%$ and $10.6 \%$, respectively, with split fertigation compared with broadcast application on the soil surface. Band placement increased leaf $\mathrm{N}$ by $7.1 \%$ relative to broadcast application on the soil surface with soil disturbance caused by band placement. Split fertigation and band placement slightly increased fruit yield, but increased marketable fruit (the total of excellent and very slightly scalded fruit) by $20.9 \%$ and $11.1 \%$ (absolute value) when compared with broadcast application of $\mathrm{N}$ and $\mathrm{P}$ and broadcast application of $\mathrm{N}$ and $\mathrm{P}$ with soil disturbance caused by band placement, respectively, and after 3 months of cold storage. No detrimental effects on fruit weight or reduction in soil amino sugar $\mathbf{N}$ were observed from lowering the $\mathrm{N}$ and $\mathrm{P}$ application rates by $20 \%$ with split fertigation. Overall, split fertigation and band placement of $\mathrm{N}$ and $\mathrm{P}$ can be used to replace single broadcast application on the soil surface on pear orchards to reduce fruit superficial scald during cold storage and improve the use efficiency of applied $N$ and $P$ in the midColumbia region of Oregon.

$\mathrm{T}$ The mid-Columbia region in Oregon produces $40 \%$ of the "winter" pears and $20 \%$ of the 'Bartlett' "summer" pears in the United States. Pear production is highly dependent on nitrogen $(\mathrm{N})$ and phosphorus $(\mathrm{P})$ fertilization to achieve optimum fruit yield and quality in the region. Presently, $\mathrm{N}$ fertilizer is applied by uniform broadcast on the soil surface in a single

\footnotetext{
${ }^{1}$ Department of Plant Sciences, The University of Tennessee, Jackson, TN 38301

${ }^{2}$ Citrus and Subtropical Products Laboratory, U.S. Department of Agriculture-Agricultural Research Service, 600 Avenue South, NW, Winter Haven, FL 33881

${ }^{3}$ North Willamette Research and Extension Center, Oregon State University, 15210 NE Miley Road, Aurora, OR 97002-9543

${ }^{4}$ Corresponding author. E-mail: xyin2@utk.edu.
}

application of $\approx 80$ to $100 \mathrm{lb} /$ acre $\mathrm{N}$ as ammonium nitrate, calcium nitrate, urea, etc. in April or May each year. The above practice has been used for many decades because it is simple and only needs to be applied once per year. However, there are growing concerns about this practice as fertilizer prices continue to rise and environmental regulations get tighter. First, $\mathrm{N}$ fertilizer is applied on the soil surface, not incorporated into the active root zone. Second, the single application rate may be too high, resulting in low $\mathrm{N}$ use efficiency and high nitrate leaching. Root systems simply cannot absorb such high $\mathrm{N}$ rates in such a short period of time. Water quality monitoring data in the region has shown that Hood River tributaries draining orchard lands have excessive $\mathrm{N}$ levels. For instance, the average nitrate/nitrite $\left(\mathrm{NO}_{3} /\right.$ $\mathrm{NO}_{2}$ ) concentration at all 10 sites monitored in the Hood River in 2001 exceeded the recommended $\mathrm{N}$ evaluation indicator value of $0.3 \mathrm{mg} \cdot \mathrm{L}^{-1} \mathrm{NO}_{3} / \mathrm{NO}_{2}$ in Oregon (Watershed Professionals Network, 1999 ) by 1.5 to 12 times (H. Coccoli, personal communications). Third, over- or underapplication may occur in any season because the 80 to 100 $\mathrm{lb} /$ acre $\mathrm{N}$ per year is recommended for a normal high pear yield. However, unlike annual crops, pear yield on a given orchard block varies considerably from year to year due to training, pruning, and weather conditions. Last, the flexibility for applying $\mathrm{N}$ fertilizer is low late in the season. Because there are fruit on the tree canopy late in the season, it is hard to move the tractor and fertilizer spreader around in the orchard, and it takes labor to do that.

Phosphorus fertilizer is applied by uniform broadcast on the soil surface at about 44 to $55 \mathrm{lb} /$ acre $\mathrm{P}$ as ammonium phosphate, etc., once (in April or May) per year along with the $\mathrm{N}$ and other fertilizers in the midColumbia region. Phosphorus use efficiency may be relatively low with this production practice because surface applied P cannot effectively

\begin{tabular}{llll}
\hline $\begin{array}{l}\text { Units } \\
\begin{array}{l}\text { To convert U.S. to SI, } \\
\text { multiply by }\end{array}\end{array}$ & U.S. unit & SI unit & $\begin{array}{l}\text { To convert SI to U.S., } \\
\text { multiply by }\end{array}$ \\
\hline 10 & $\%$ & $\mathrm{~g} \cdot \mathrm{kg}^{-1}$ & 0.1 \\
0.3048 & $\mathrm{ft}$ & $\mathrm{m}$ & 3.2808 \\
2.54 & inch(es) & $\mathrm{cm}$ & 0.3937 \\
25.4 & inch(es) & $\mathrm{mm}$ & 0.0394 \\
0.4536 & lb & $\mathrm{kg}$ & 2.2046 \\
1.1209 & $\mathrm{lb} / \mathrm{acre}$ & $\mathrm{kg} \cdot \mathrm{ha}^{-1}$ & 0.8922 \\
4.4482 & $\mathrm{lbf}$ & $\mathrm{N}$ & 0.2248 \\
28.3495 & $\mathrm{oz}$ & $\mathrm{g}$ & 0.0353 \\
1 & $\mathrm{ppm}$ & $\mathrm{mg} \cdot \mathrm{kg}^{-1}$ & 1 \\
$\left({ }^{\circ} \mathrm{F}-32\right) \div 1.8$ & ${ }^{\circ} \mathrm{F}$ & ${ }^{\circ} \mathrm{C}$ & $1.8 \times{ }^{\circ}(\mathrm{C})+32$ \\
& & &
\end{tabular}


infiltrate into the active root zone due to poor mobility of $\mathrm{P}$ in soil (Lauer, 1988). Poor downward movement of surface applied $\mathrm{P}$ into the root zone of many orchard soils has long been recognized (Wander, 1947).

In contrast, split $\mathrm{N}$ and $\mathrm{P}$ fertigation offers increased flexibility in managing orchard $\mathrm{N}$ and $\mathrm{P}$ programs because of the potential to closely synchronize nutrient application with plant demand (Haynes, 1985). Fertigation of $\mathrm{N}$ and $\mathrm{P}$ is a nutrient management practice that applies $\mathrm{N}$ and $\mathrm{P}$ fertilizers with the irrigation water by injecting fertilizer solution into the flowing water of an irrigation system. Split N and P fertigation is assumed to have the potential to increase $\mathrm{N}$ and $\mathrm{P}$ use efficiencies based on the following reasons: 1) Fertilizers are applied with irrigation water and can easily travel into the active root zone; 2 ) $\mathrm{N}$ and $\mathrm{P}$ application rates per time are substantially lowered due to split applications; 3 ) over- and underapplications of $\mathrm{N}$ and $\mathrm{P}$ are avoidable because growers are provided with opportunities to adjust the $\mathrm{N}$ and $\mathrm{P}$ application rates during the season; and 4) flexibility for applying $\mathrm{N}$ and $\mathrm{P}$ late in the season is high because no tractor or fertilizer spreader is needed to move around in the orchard. In addition, split $\mathrm{N}$ and $\mathrm{P}$ fertigation may reduce soil compaction and does not require much labor due to an easily operated automated system.

Prior studies in bearing orchards have shown fruit tree responses to fertigation are site and management specific. Higher $\mathrm{N}$ use efficiency (Dasberg et al., 1988; Klein et al., 1989, 1999; Sanchez et al., 2003), comparable or enhanced yield (Sanchez et al., 2003), and improved weed control were frequently observed with split $\mathrm{N}$ fertigation compared with surface broadcasting of $\mathrm{N}$ in several fruit species. For example, yield of tart cherry (Prunus avium) was comparable or even higher, but nitrate leaching dramatically diminished when $\mathrm{N}$ fertilizer was fertigated at a reduced rate during a 6-year field study in Michigan (Sanchez et al., 2003). However, limited research has been done pertaining to the effects of fertigation on fruit storability and quality (Ericson, 1993).

Another alternate $\mathrm{N}$ and $\mathrm{P}$ fertilizer management is band placement.
Band placement can also deliver fertilizer down into the active root zone in bands and reduce the contact of fertilizer with soil, but requires a narrower, more controlled applicator. In contrast, surface broadcasting is usually easier and faster because the fertilizer can be applied in a wide swath. Little research has been done about the benefits of band placement of $\mathrm{N}$ and $\mathrm{P}$ over surface broadcasting. Previous investigations in annual crops showed improved P use efficiency resulting in yield increases from band placement relative to surface broadcasting on soils with low $\mathrm{P}$ levels or high $\mathrm{P}$ fixation capacity, particularly under no-tillage systems (Eckert and Johnson, 1985; Hairston et al., 1990).

Because single broadcast application of $\mathrm{N}$ and $\mathrm{P}$ on the soil surface results in low use efficiency of applied $\mathrm{N}$ and $\mathrm{P}$ in pear production systems in Oregon and the Pacific northwestern United States, the development of more efficient $\mathrm{N}$ and $\mathrm{P}$ management practices is needed. Thus far, little research has been done to address the possibilities of using split $\mathrm{N}$ and $\mathrm{P}$ fertigation and band placement of $\mathrm{N}$ and $\mathrm{P}$ as alternate $\mathrm{N}$ and $\mathrm{P}$ management practices on pears and other fruit trees in Oregon. The objective of this study was to evaluate the effects of split fertigation and band placement as alternate $\mathrm{N}$ and $\mathrm{P}$ management practices on tree nutrition, fruit yield, quality, and superficial scald of pears, as well as soil nutrient supply compared with the current $\mathrm{N}$ and $\mathrm{P}$ management practice of single broadcast application of $\mathrm{N}$ and $\mathrm{P}$ on the soil surface in the mid-Columbia region of Oregon.

\section{Materials and methods}

SITE DESCRIPTION AND EXPERIMENTAL DESIGN. A field experiment was conducted from Mar. 2005 through Nov. 2006 on bearing 'Anjou' pears growing on a Parkdale loam soil (medial, mesic Umbric Vitrandepts) on a commercial orchard near Parkdale, OR. The Parkdale series are well-drained soils on uplands formed by deep mudflow that is moderately permeable and high in pyroclastic materials. The orchard block used in this study was planted at $18 \mathrm{ft}$ between rows and $10 \mathrm{ft}$ between trees in 1972 with second-leaf 'Anjou' pear on Seedling rootstock. The trees were trained to central leaders. Single-line surface drip irrigation and single surface broadcasting of $\mathrm{N}$ and $\mathrm{P}$ fertilizers had been used to manage this block before the initiation of this trial.

The study was conducted using a randomized complete block design with four replications. Each plot consisted of five trees. The following four treatments were evaluated: 1) $\mathrm{N}$ and $P$ fertilizers were broadcast applied on the soil surface in a 10 -ft-wide, weedfree strip centered on the tree row (broadcast); 2) $\mathrm{N}$ and $\mathrm{P}$ were banded in $1 \times 1-f t$ ditches (width $\times$ depth) on both sides of tree rows (band); 3 ) $1 \times$ $\mathrm{l}$-ft ditches were dug on both sides of the tree row using the band placement equipment and the dug soil was then completely returned to the ditch without any fertilizer being banded; after the soil disturbance was completed, $\mathrm{N}$ and $\mathrm{P}$ were broadcast applied on the soil surface in a 10 -ftwide, weed-free strip centered on the tree row (broadcast with soil disturbance); 4) $\mathrm{N}$ and $\mathrm{P}$ were fertigated in five split but equal applications throughout the growing season (fertigation).

Nitrogen and phosphate fertilizers were applied at $100 \mathrm{lb} /$ acre $\mathrm{N}$ and $55 \mathrm{lb} /$ acre $\mathrm{P}$, respectively, to treatments 1,2 , and 3 , whereas treatment 4 received only $80 \mathrm{lb} /$ acre $\mathrm{N}$ and $44 \mathrm{lb} /$ acre P. Nitrogen and P fertilizers for treatments 1,2 , and 3 were applied once in April each season. However, the $\mathrm{N}$ and $\mathrm{P}$ fertilizers for treatment 4 were split into five equal applications during May to August at a 3-week interval each year. Urea (46N-0P-0K), ammonium phosphate $(11 \mathrm{~N}-23 \mathrm{P}-0 \mathrm{~K})$, and potassium muriate $(0 \mathrm{~N}-0 \mathrm{P}-50 \mathrm{~K})$ were used for treatments 1,2 , and 3 . Liquid fertilizer $(6 \mathrm{~N}-10.5 \mathrm{P}-5 \mathrm{~K})$ was used to meet the $\mathrm{P}$ requirement for treatment 4 , whereas $\mathrm{N}$ was provided by using liquid fertilizer and urea. All four treatments received an equal $\mathrm{K}$ application rate. The irrigation lines were flushed for at least $30 \mathrm{~min}$ after fertigation each time.

During experimentation, irrigation was conducted separately for each individual plot on a weekly basis from May to September each season according to the tree water needs. Irrigation was applied via a pressure-compensating drip line located under each tree in the tree row for all the treatments. 
Each treatment received the same total amount of water each season. Weed, disease, and insect control was managed using the practices that were commonly used for commercial production, and all the treatments were under the identical management.

Plant and soll SAMPLING AND ANALYSIS. A leaf sample was taken randomly from each individual plot in October, $\approx 1$ month after fruit harvest in 2005 and 2006. Each year, the samples were collected from the same trees and under similar weather conditions. Each leaf sample consisted of 30 new but fully developed midterminal leaves from current year shoots at $5 \mathrm{ft}$ above the ground in the tree canopy. All leaf samples were washed with tap water and rinsed with distilled water, oven-dried at $65{ }^{\circ} \mathrm{C}$, and ground to pass through a $1-\mathrm{mm}$ sieve. Total $\mathrm{N}$ was determined using a combustion method with a nitrogen/ carbon analyzer (NA 1500; Carlo Erba Instruments, Milan, Italy) (Gavlak et al., 1994). Leaf samples were digested in a microwave digestion oven (MDS-2100; CEM, Matthews, NC) using nitric acid and hydrogen peroxide, and the digest was analyzed for total $\mathrm{P}$, potassium (K), calcium (Ca), magnesium ( $\mathrm{Mg}$ ), sulfur $(\mathrm{S})$, boron $(\mathrm{B})$, zinc $(\mathrm{Zn})$, manganese $(\mathrm{Mn})$, copper $(\mathrm{Cu})$, and iron $(\mathrm{Fe})$ on an inductively coupled plasma spectrometer (model 1100; Thermo Jarrel Ash, Franklin, MA) (Gavlak et al., 1994).

A composite soil sample was collected at the 0 to $1-\mathrm{ft}$ depth for each plot in October each year. Ten soil cores per sample were randomly collected from the area under the tree canopy where no herbicides were applied with a 1 -inch-diameter soil probe after removing visible tree and weed residue from the soil surface by hand. Each sample was placed in a soil-sampling bag that was then stored in a cold storage room at $1{ }^{\circ} \mathrm{C}$. All samples were air-dried, ground to pass through a 2 -mm sieve, and thoroughly mixed. Soil ammonium $\left(\mathrm{NH}_{4}{ }^{+}\right), \mathrm{NO}_{3}{ }^{-}$, and available $\mathrm{P}$, $\mathrm{K}, \mathrm{Ca}, \mathrm{Mg}, \mathrm{S}, \mathrm{B}, \mathrm{Zn}, \mathrm{Mn}, \mathrm{Cu}$, and Fe were extracted using the Mehlich III method (Mehlich, 1984). Soil amino sugar $\mathrm{N}$ was extracted with sodium hydroxide $(\mathrm{NaOH})$ (Khan et al., 2001). Soil total $\mathrm{N}$ was determined by combustion (Gavlak et al., 1994). Soil total P concentration was measured using the Bray II method (Frank et al., 1998). Soil pH was determined in a $1: 1$ (soil:water) solution (Watson and Brown, 1998). Soil organic matter was measured using the loss-on-ignition method (Combs and Nathan, 1998).

TREe GROWTH AND FRUIT YIELD, QUALITY, AND STORABILITY. Tree trunk cross-sectional area was measured at $24 \mathrm{~cm}$ aboveground for each plot in both years. Fruit yield was determined by harvesting three central trees from each plot in September each year. A fruit sample was randomly collected from each plot at harvest. The following measurements were taken on an individual plot basis at harvest each season: Fruit firmness was measured using a fruit texture analyzer (model GS-14; Guss Manufacturing, Strand, South Africa). Ten fruit per sample were tested with an 8 -mm plunger that penetrates $9 \mathrm{~mm}$ in $0.9 \mathrm{~s}$. Fruit juice was extracted using a juicer (model 6001; Acme Juicer, Sierra Madre, CA) with a milk filter (Schwartz Manufacturing, Two Rivers, WI) at about 2500 to $3000 g_{n}$ for $1 \mathrm{~min}$, and was used to determine sugar and titratable acidity concentrations. Fruit sugar content (\%) was determined using a digital refractometer (PRl0l $\alpha$; Atago, Tokyo). Fruit titratable acidity was determined using a titration system (model T80/20; Schott-Gerate, Hofheim, Germany). Fruit weight was measured by running the fruit through a packing line (MSE 2000; Greefa, Tricht, The Netherlands). Fruit superficial scald incidence was visually evaluated after the fruit had been stored for 3 months at $-0.5{ }^{\circ} \mathrm{C}$ plus $7 \mathrm{~d}$ at $20^{\circ} \mathrm{C}$ each year. Five categories of excellent, very slightly scalded, slightly scalded, moderately scalded, and severely scalded fruit were employed in this evaluation. The marketable fruit consisted of excellent and very slightly scalded fruit; the unmarketable fruit due to scald included slightly, moderately, and severely scalded fruit.

Statistical analysis. Analysis of variance (ANOVA) was conducted for each measurement across years because of the error homogeneity across years using the ANOVA procedure of SAS (version 9.1; SAS Institute, Cary, NC). The variance was analyzed in leaf nutrient concentrations, yield, quality, and storability of fruit, as well as soil nutrient concentrations with four treatments arranged in a randomized complete block design replicated four times. Mean separations for each measurement were accomplished using the Fisher's protected least significant difference test (Kuehl, 1994). Probability levels less than 0.05 were designated as significant.

Presentation and discussion of the results in "Results and discussion" focus on the average treatment effects over the 2 years because no significant treatment $x$ year interactions were observed on any of the measurements in this study. The year effects are not presented or discussed in this article.

\section{Results and discussion}

LEAF NUTRIENT CONCENTRATIONS AFTER FRUIT HARVEST. Averages from 2005 and 2006 indicated that split $\mathrm{N}$ and $\mathrm{P}$ fertigation resulted in greater leaf $\mathrm{N}$ concentration $\approx 1$ month after fruit harvest compared with broadcast application of $\mathrm{N}$ and $\mathrm{P}$ on the soil surface (Table 1). The increase in leaf $\mathrm{N}$ was $10.0 \%$ with split fertigation over broadcast application. Band placement of $\mathrm{N}$ and $\mathrm{P}$ increased leaf $\mathrm{N}$ concentration by $7.1 \%$ relative to broadcast application with soil disturbance caused by band placement. Leaf P concentration was increased by $10.6 \%$ with split fertigation compared with broadcast application averaged over 2005 and 2006 (Table 1). However, no increase in leaf $\mathrm{P}$ was observed with band placement. Overall, our results suggest that split fertigation improves leaf $\mathrm{N}$ and $\mathrm{P}$ nutrition, and band placement increases leaf $\mathrm{N}$ concentration compared with broadcast application.

Similar to leaf $\mathrm{N}$, leaf $\mathrm{K}$ concentration was increased by $23.5 \%$ with split fertigation compared with broadcast application (Table 1). Band placement resulted in a $32.2 \%$ increase in leaf $\mathrm{K}$ over broadcast application, with soil disturbance caused by band placement. Leaf $S$ and $\mathrm{B}$ concentrations were enhanced by $19.8 \%$ and $14.6 \%$, respectively, with split fertigation relative to broadcast application averaged over the 2 years. However, no effects of split fertigation or band placement were observed on average leaf $\mathrm{Ca}$, $\mathrm{Mg}, \mathrm{Zn}, \mathrm{Mn}, \mathrm{Cu}$, or Fe concentration over the 2-year period. 
Table 1. Effects of split fertigation and band placement of nitrogen $(N)$ and phosphorus $(P)$ on pear leaf $N, P$, potassium $(K)$, calcium (Ca), magnesium (Mg), sulfur (S), boron (B), zinc $(\mathrm{Zn})$, manganese $(\mathrm{Mn})$, copper $(\mathrm{Cu})$, and iron (Fe) concentrations after pear harvest averaged over 2005 and 2006.

\begin{tabular}{|c|c|c|c|c|c|c|c|c|c|c|c|}
\hline Treatment $^{\mathrm{z}}$ & $\underset{\left(\mathrm{g} \cdot \mathrm{kg}^{-1}\right)^{\mathrm{y}}}{\mathrm{N}}$ & $\underset{\left(\mathrm{g} \cdot \mathrm{kg}^{-1}\right)}{\mathrm{P}}$ & $\underset{\left(\mathrm{g} \cdot \mathrm{kg}^{-1}\right)}{\mathrm{K}}$ & $\begin{array}{c}\mathrm{Ca} \\
\left(\mathrm{g} \cdot \mathrm{kg}^{-1}\right)\end{array}$ & $\underset{\left(\mathrm{g} \cdot \mathrm{kg}^{-1}\right)}{\mathrm{Mg}}$ & $\begin{array}{c}\mathrm{S} \\
\left(\mathrm{g} \cdot \mathrm{kg}^{-1}\right)\end{array}$ & $\begin{array}{c}\text { B } \\
\left(\mathrm{mg} \cdot \mathrm{kg}^{-1}\right)^{y}\end{array}$ & $\begin{array}{c}\mathrm{Zn} \\
\left(\mathrm{mg} \cdot \mathrm{kg}^{-1}\right)\end{array}$ & $\underset{\left(\mathrm{mg} \cdot \mathrm{kg}^{-1}\right)}{\mathrm{Mn}}$ & $\underset{\left(\mathrm{mg} \cdot \mathrm{kg}^{-1}\right)}{\mathrm{Cu}}$ & $\begin{array}{c}\mathrm{Fe} \\
\left(\mathrm{mg} \cdot \mathrm{kg}^{-1}\right)\end{array}$ \\
\hline Broadcast & $20.1 b^{x}$ & $1.23 \mathrm{~b}$ & $9.8 \mathrm{~b}$ & 22.7 & 2.72 & $2.93 \mathrm{~b}$ & $190.7 \mathrm{~b}$ & 468.6 & 69.7 & 6.58 & 81.2 \\
\hline Band & $21.2 \mathrm{a}$ & $1.30 \mathrm{ab}$ & $11.9 \mathrm{a}$ & 21.8 & 2.63 & $3.15 \mathrm{~b}$ & $187.4 \mathrm{~b}$ & 458.2 & 73.5 & 7.68 & 73.2 \\
\hline $\begin{array}{l}\text { Broadcast with soil } \\
\text { disturbance }\end{array}$ & $19.8 \mathrm{~b}$ & $1.31 \mathrm{ab}$ & $9.0 \mathrm{~b}$ & 22.7 & 2.79 & $3.03 \mathrm{~b}$ & $169.7 \mathrm{~b}$ & 422.3 & 75.6 & 7.86 & 73.2 \\
\hline Fertigation & $22.1 \mathrm{a}$ & $1.36 \mathrm{a}$ & $12.1 \mathrm{a}$ & 21.8 & 2.74 & $3.51 \mathrm{a}$ & $218.6 \mathrm{a}$ & 482.8 & 69.0 & 7.56 & 83.3 \\
\hline
\end{tabular}

${ }^{2}$ Broadcast $=\mathrm{N}$ and $\mathrm{P}$ fertilizers were broadcast applied on the soil surface in a 10 - $\mathrm{ft}$-wide, weed-free strip centered on the tree row; Band $=\mathrm{N}$ and $\mathrm{P}$ were banded in $\mathrm{l} \times \mathrm{l}$ - $\mathrm{ft}$ ditches (width $\times$ depth) on both sides of tree rows; Broadcast with soil disturbance $=1 \times 1$-ft ditches were dug on both sides of the tree row using the band placement equipment, then the dug soil was completely returned to the ditch without any fertilizer being banded; after the soil disturbance was completed, $\mathrm{N}$ and $\mathrm{P}$ were broadcast applied on the soil surface in a 10 -ft-wide, weed-free strip centered on the tree row; Fertigation $=\mathrm{N}$ and $\mathrm{P}$ were fertigated in five split but equal applications throughout the growing season; $\mathrm{l} \mathrm{ft}=0.3048 \mathrm{~m}$.

$\mathrm{l} \mathrm{g} \cdot \mathrm{kg}^{-1}=0.1 \%, 1 \mathrm{mg} \cdot \mathrm{kg}^{-1}=1 \mathrm{ppm}$

'Values in column followed by the same letter are not significantly different via Fisher's protected least significant difference test at $5 \%$ probability level.

${ }^{w *}$ and ${ }^{* *}$ indicate the treatment effect is statistically significant at $5 \%$ and $1 \%$ probability level, respectively; nonsignificant effect is denoted by Ns.

Improved tree $\mathrm{N}$ and $\mathrm{P}$ nutrition with split fertigation may be attributed to the following: First, fertilizer is delivered directly into the active root zone, and second, $\mathrm{N}$ and $\mathrm{P}$ rates in each application are substantially lowered due to split application. Increases in leaf $\mathrm{N}$ levels with band placement may be resultant from the direct delivery of $\mathrm{N}$ to the root zone and thus reduction of $\mathrm{N}$ losses due to volatilization and runoff.

The trends of our leaf $\mathrm{N}$ results agree with some prior studies on other tree species that have indicated that split fertigation could supply adequate mineral nutrition to fruit trees, even at a reduced application rate, relative to broadcast application, but the extent of responses differs. Worley et al. (1995) found that no reduction in leaf mineral nutrient concentrations of pecans occurred when $100 \mathrm{lb} /$ acre of $\mathrm{N}$ was fertigated compared with $200 \mathrm{lb} /$ acre $\mathrm{N}$ applied via broadcast application under a drip irrigation system in a 10 -year long-term study in Georgia. Our leaf $P$ results show a similar tendency to those of Neilsen et al. (1994) who found $\mathrm{P}$ fertigation increased leaf $\mathrm{P}$ concentration of apple (Malus $\times$ domestica) relative to broadcast application in the first growing season. Enhanced mobility of $\mathrm{P}$ in soil under fertigation (O'Neil et al., 1979; Rauschkolb et al., 1976) may be responsible for improved tree $\mathrm{P}$ nutrition.

Previous research has shown that leaf $\mathrm{N}$ and $\mathrm{P}$ concentrations are indicative of $\mathrm{N}$ and $\mathrm{P}$ nutrition status of bearing pear trees (Hart et al., 1997).
Leaf nutrient concentrations in October $\approx 1$ month after fruit harvest are commonly used as references to evaluate the nutrient management program implemented on the present season and to make fertilizer recommendations for the coming season in the mid-Columbia region of Oregon and other regions in the Pacific northwestern United States. Total $\mathrm{N}$ concentration of $2.01 \%$ to $2.35 \%$ and $\mathrm{P}$ concentration of $0.14 \%$ to $0.45 \%$ on a dry leaf weight basis are generally considered sufficient for optimum tree growth and fruit production of 'Anjou' pear (Hart et al., 1997). Average leaf N concentrations under split fertigation and band placement in this study were 22 to $21 \mathrm{~g} \cdot \mathrm{kg}^{-1}$, respectively; both well above the lower threshold for the normal range, and were considered adequate. Average leaf $\mathrm{P}$ concentrations with split fertigation and band placement were 1.4 to $1.3 \mathrm{~g} \cdot \mathrm{kg}^{-1}$, respectively; both around the lower threshold for the normal range, and were considered adequate and slightly below normal, respectively. No visual deficiency or toxicity symptoms of $\mathrm{N}$ or $\mathrm{P}$ were noted in any treatment of this study during the 2 years of experimentation.

SoIL NUTRIENT LEVEL AFTER FRUIT HARVEST. Soil $\mathrm{NH}_{4}-\mathrm{N}$, amino sugar $\mathrm{N}$, estimated $\mathrm{N}$ release, or total $\mathrm{N}$ concentration was not reduced with split fertigation compared with broadcast application, although the $\mathrm{N}$ fertilizer application rate was lowered by $20 \%$ in the split fertigation treatment each year (Table 2). However, soil $\mathrm{NO}_{3}-\mathrm{N}$ concentration was lowered under split fertigation relative to broadcast application. Lower $\mathrm{NO}_{3}-\mathrm{N}$ with split fertigation may be attributable to the greater uptake of $\mathrm{NO}_{3}-\mathrm{N}$ from the soil. The difference in available P or total P concentration was not statistically significant between split fertigation and broadcast application. No difference in soil $\mathrm{NH}_{4}-\mathrm{N}$, amino sugar $\mathrm{N}$, total $\mathrm{N}$, available $\mathrm{P}$, or total $\mathrm{P}$ was observed between band placement and broadcast application with soil disturbance caused by band placement. Soil $\mathrm{pH}$ was higher with split fertigation relative to broadcast application in our study. In contrast, lower $\mathrm{pH}$ around drip emitters in orchard is sometimes the result of $\mathrm{N}$ fertigation (Edwards et al., 1982). Higher soil pH with split fertigation than broadcast application in our study could be attributed to the fact that the $\mathrm{N}$ rate used for split fertigation was only $80 \%$ of the $\mathrm{N}$ rate under broadcast application.

Overall, our results suggest that split fertigation at $80 \%$ of the recommended normal $\mathrm{N}$ and $\mathrm{P}$ rates under broadcast application could supply adequate $\mathrm{N}$ and $\mathrm{P}$ nutrition to bearing pear trees in the mid-Columbia region of Oregon. Split-fertigated $\mathrm{N}$ and $\mathrm{P}$ application generally shows no negative effect on indigenous soil $\mathrm{N}$ and $\mathrm{P}$ levels, but increases use efficiency of applied $\mathrm{N}$ and $\mathrm{P}$ when compared with the current broadcast application practices.

TREe GROWTH AND FRUIT YIELD AND QUALITY. Tree trunk crosssectional area did not differ among the four treatments in any year (data not presented). Fruit yields were 
Table 2. Effects of split fertigation and band placement of nitrogen $(\mathrm{N})$ and phosphorus $(\mathrm{P})$ on soil ammonium-nitrogen $\left(\mathrm{NH}^{+}{ }_{4}-\mathrm{N}\right)$, nitrate-nitrogen $\left(\mathrm{NO}^{-}{ }_{3}-\mathrm{N}\right)$, amino sugar $\mathrm{N}$, estimated $\mathrm{N}$ release $(\mathrm{ENR})$, total $\mathrm{N}$, available $\mathrm{P}$, total $\mathrm{P}$, pH, and organic matter after pear harvest averaged over 2005 and 2006.

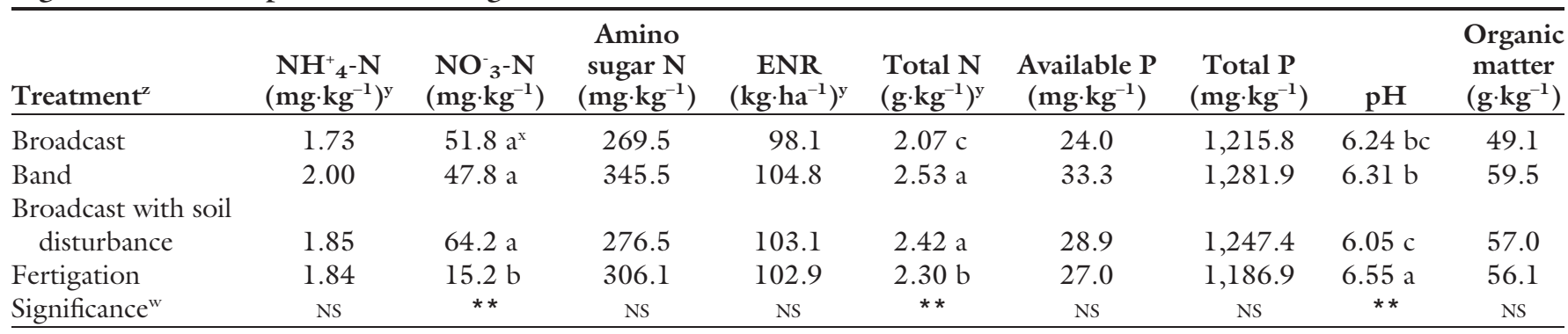

${ }^{2}$ Broadcast $=\mathrm{N}$ and $\mathrm{P}$ fertilizers were broadcast applied on the soil surface in a 10 - $\mathrm{ft}$-wide, weed-free strip centered on the tree row; Band $=\mathrm{N}$ and $\mathrm{P}$ were banded in $\mathrm{l} \times \mathrm{l}$ - $\mathrm{ft}$ ditches (width $\times$ depth) on both sides of tree rows; Broadcast with soil disturbance $=1 \times 1$-ft ditches were dug on both sides of the tree row using the band placement equipment, then the dug soil was completely returned to the ditch without any fertilizer being banded; after the soil disturbance was completed, $\mathrm{N}$ and $\mathrm{P}$ were broadcast applied on the soil surface in a 10 -ft-wide, weed-free strip centered on the tree row; Fertigation $=\mathrm{N}$ and $\mathrm{P}$ were fertigated in five split but equal applications throughout the growing season; $1 \mathrm{ft}=0.3048 \mathrm{~m}$

${ }^{\mathrm{y}} \mathrm{l} \mathrm{mg} \cdot \mathrm{kg}^{-1}=1 \mathrm{ppm}, \mathrm{l} \mathrm{kg} \cdot \mathrm{ha}^{-1}=0.8922 \mathrm{lb} / \mathrm{acre}, \mathrm{l} \mathrm{g} \cdot \mathrm{kg}^{-1}=0.1 \%$

'Values in column followed by the same letter are not significantly different via Fisher's protected least significant difference test at $5 \%$ probability level.

$w * *$ indicates the treatment effect is statistically significant at $1 \%$ probability level; nonsignificant effect is denoted by NS.

comparable among the four treatments averaged over 2005 and 2006 (Table 3). Basically, the treatment effects on yields did not differ between the 2 years, which was why the 2-year results were combined to perform statistical analyses. No downward trend in treatment effects on yields was observed from year 1 to year 2 . The effects of treatments on cumulative yields over the 2-year period were similar to those for individual years. Additionally, the yields of each treatment were similar over the 2 years (data not shown). Overall, our results indicate that split fertigation at $80 \%$ of the recommended $\mathrm{N}$ and $\mathrm{P}$ application rates for broadcast application can provide adequate $\mathrm{N}$ and $\mathrm{P}$ nutrition for bearing pear trees over the long run. Fruit firmness at harvest was increased by $5.6 \%$ with split fertigation relative to broadcast application when the 2-year results were combined (Table 3 ). Sugar and titratable acidity concentrations in fruit were $4.8 \%$ and $13.1 \%$ greater, respectively, with band placement compared with broadcast application with soil disturbance caused by band placement.

According to the packing line output data, split fertigation and band placement produced larger fruit at harvest than their respective control (Fig. 1). Split fertigation produced a higher percentage of fruit in the weight category of 309 to $999 \mathrm{~g} /$ fruit, but a lower percentage of fruit in the 211 to 236 and 236 to $268 \mathrm{~g} /$ fruit categories compared with broadcast application in the 2 -year averages.

Table 3. Effects of split fertigation and band placement of nitrogen $(\mathrm{N})$ and phosphorus $(\mathrm{P})$ on pear fruit yield and quality at harvest averaged over 2005 and 2006.

\begin{tabular}{|c|c|c|c|c|}
\hline Treatment $^{\mathrm{z}}$ & $\begin{array}{c}\text { Yield } \\
\left(^{(\mathrm{kg} / \text { tree })^{\mathrm{y}}}\right.\end{array}$ & $\begin{array}{c}\text { Firmness } \\
(\text { lbf })^{\mathrm{y}}\end{array}$ & $\begin{array}{c}\text { Sugar } \\
(\%)\end{array}$ & $\begin{array}{c}\text { Titratable acidity } \\
{[\text { malic acid }} \\
(\mathrm{meq} / 100 \mathrm{~mL})]^{\mathrm{y}}\end{array}$ \\
\hline Broadcast & 100.4 & $14.3 \mathrm{~b}^{\mathrm{x}}$ & $13.0 \mathrm{ab}$ & $4.28 \mathrm{ab}$ \\
\hline Band & 110.2 & $14.3 \mathrm{~b}$ & $13.2 \mathrm{a}$ & $4.57 \mathrm{a}$ \\
\hline Broadcast with soil disturbance & 103.5 & $14.5 \mathrm{~b}$ & $12.6 \mathrm{~b}$ & $4.04 \mathrm{~b}$ \\
\hline Fertigation & 106.6 & $15.2 \mathrm{a}$ & $12.6 \mathrm{~b}$ & $4.25 \mathrm{ab}$ \\
\hline Significance $^{w}$ & NS & * & * & * \\
\hline
\end{tabular}

${ }^{2}$ Broadcast $=\mathrm{N}$ and $\mathrm{P}$ fertilizers were broadcast applied on the soil surface in a 10 -ft-wide, weed-free strip centered on the tree row; Band $=\mathrm{N}$ and $\mathrm{P}$ were banded in $\mathrm{l} \times \mathrm{l}$ - $\mathrm{ft}$ ditches (width $\times$ depth) on both sides of tree rows; Broadcast with soil disturbance $=1 \times 1-\mathrm{ft}$ ditches were dug on both sides of the tree row using the band placement equipment, then the dug soil was completely returned to the ditch without any fertilizer being banded; after the soil disturbance was completed, $\mathrm{N}$ and $\mathrm{P}$ were broadcast applied on the soil surface in a 10 -ft-wide, weed-free strip centered on the tree row; Fertigation $=\mathrm{N}$ and $\mathrm{P}$ were fertigated in five split but equal applications throughout the growing season; $1 \mathrm{ft}=0.3048 \mathrm{~m}$.

${ }^{y} \mathrm{l} \mathrm{kg}=2.2046 \mathrm{lb}, \mathrm{lbf}=4.4482 \mathrm{~N}, \mathrm{l} \mathrm{meq} / \mathrm{l} 00 \mathrm{~mL}=0.6700 \mathrm{mg} \cdot \mathrm{g}^{-1}$

'Values in column followed by the same letter are not significantly different via Fisher's protected least significant difference test at $5 \%$ probability level.

w* indicates the treatment effect is statistically significant at $5 \%$ probability level; nonsignificant effect is denoted by NS.

Band placement resulted in a higher percentage of fruit in the categories of 211 to 236 and 236 to $268 \mathrm{~g}$ /fruit, but a lower percentage of fruit in the 0 to $14 \mathrm{l} \mathrm{g} /$ fruit category relative to broadcasting application with soil disturbance. Greater N levels in leaf with split fertigation and band placement may correlate with the higher percentage of larger fruit, which is in agreement with those on nectarine (Crisosto et al., 1997).

Previous research on pear trees (Sanchez and Righetti, 1990; Sanchez et al., 1990a, 1990b) showed that nutrient reserves in the trees are the main source for developing tissues before petal fall. After petal fall, tree nutrition is mainly from the uptake of applied fertilizers and soil nutrients during the current season. Therefore, the $\mathrm{N}$ and $\mathrm{P}$ reserves in the trees from the previous year may have some buffering effects on the treatment effects of year $\mathrm{l}$ in this study because these nutrient reserves were uptaken from the applied fertilizers and soil nutrients by the trees during the year before this study; however, the tree $\mathrm{N}$ and $\mathrm{P}$ reserves from the year before this study should not have significant effects on the treatment effects of year 2 in this study. Our results show that split fertigation at $80 \%$ of the recommended $\mathrm{N}$ and $\mathrm{P}$ application rates for broadcast application can supply adequate $\mathrm{N}$ and $\mathrm{P}$ nutrition needed for the normal growth of bearing pear trees, which indicates that split fertigation enhances $\mathrm{N}$ and $\mathrm{P}$ use efficiency 
and reduces $\mathrm{N}$ and $\mathrm{P}$ losses relative to broadcast application.

Similar to our results, some previous research has shown that fertigation can reduce the amount of $\mathrm{N}$ applied to orchards while maintaining equal or increased tree fruit productivity relative to broadcast application. However, the magnitude of reduction in $\mathrm{N}$ application rates via fertigation varies with locations. Sanchez et al. (2003) reported that yield of tart cherry was comparable or even higher when $\mathrm{N}$ fertilizer was fertigated at a reduced annual rate of $66 \mathrm{~kg} \cdot \mathrm{ha}^{-1} \mathrm{~N}$ relative to $113 \mathrm{~kg} \cdot \mathrm{ha}^{-1} \mathrm{~N}$ of surface broadcast $\mathrm{N}$ during a 6 -year field study in Michigan. Neilsen et al. (1994) observed that fertigated $\mathrm{P}$ increased apple yield in the first fruiting season in western Canada. Overall, the amount of $\mathrm{N}$ or $\mathrm{P}$ fertilizer that can be saved under fertigation is site- and management-specific, and is highly related to soil properties, irrigation system, fertigation and irrigation scheduling, and microclimate.

FRUIT SUPERFICIAL SCALD. Superficial scald of pear fruit is one of the major disorders that occur during cold storage before the fruit goes to the retail markets. Interestingly, split fertigation and band placement increased the total percentage of marketable fruit (the total of excellent and very slightly scalded fruit) by

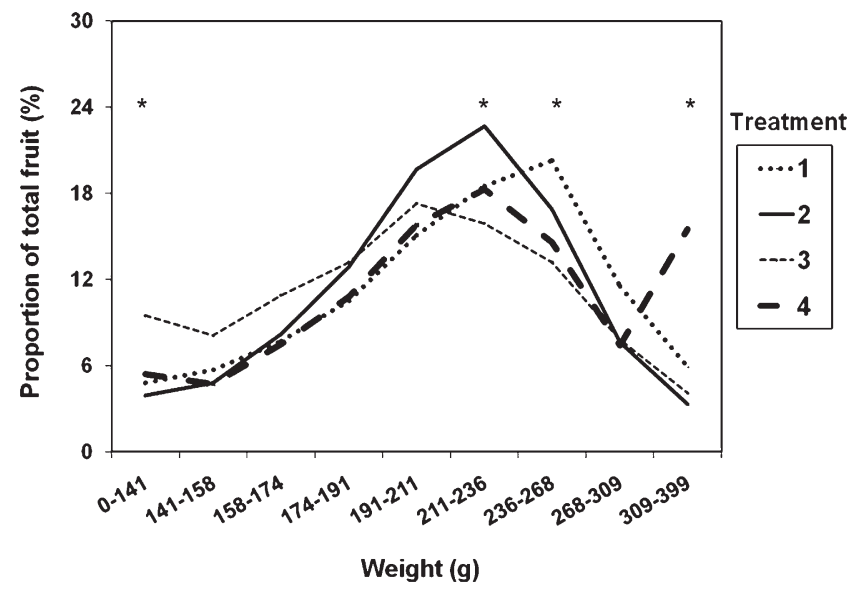

Fig. 1. Effects of split fertigation and band placement of nitrogen $(\mathrm{N})$ and phosphorus (P) on pear fruit weight at harvest. 1) N and P fertilizers were broadcast applied on the soil surface in a 10 - $\mathrm{ft}$-wide, weed-free strip centered on the tree row; 2) $\mathbf{N}$ and $P$ were banded in $1 \times 1-f t$ ditches (width $\times$ depth) on both sides of tree rows; 3) $1 \times 1$-ft ditches were dug on both sides of the tree row using the band placement equipment, then the dug soil was completely returned to the ditch without any fertilizer being banded; after the soil disturbance was completed, $\mathrm{N}$ and $\mathrm{P}$ were broadcast-applied on the soil surface in a 10 - $\mathrm{ft}$-wide, weed-free strip centered on the tree row; 4) $\mathrm{N}$ and $\mathrm{P}$ were fertigated in five split but equal applications throughout the growing season. Asterisks indicate significant treatment effects at $P=0.05 ; 1 \mathrm{ft}=0.3048 \mathrm{~m}, 1 \mathrm{~g}=0.0353 \mathrm{oz}$.

$20.9 \%$ and $11.1 \%$ (absolute value) on average for 2005 and 2006 compared with their respective control after the fruit had been stored in a cold storage room at $-0.5^{\circ} \mathrm{C}$ for 3 months plus $7 \mathrm{~d}$ at $20{ }^{\circ} \mathrm{C}$ (Table 4). The increase in marketable fruit, which resulted from the reduction in slight, moderate, and severe scald incidences, could significantly enhance grower profitability. No fruit superficial scald incidences were documented in the prior fertigation and band placement of $\mathrm{N}$ and $\mathrm{P}$ on pear studies. Our results show that reduction in fruit superficial scald during cold storage is another notable benefit with split fertigation and band placement. Reduction in superficial scald under split fertigation and band placement is likely attributed to the improved K nutrition in the fruit even though no direct measurements of fruit $\mathrm{K}$ were conducted in this study. However, higher leaf $\mathrm{K}$ levels usually mean higher fruit $\mathrm{K}$ concentrations under split fertigation and band placement.

\section{Conclusions}

Nitrogen and $\mathrm{P}$ applications at $80 \%$ of the current broadcast application rates and fertigated in five equal split applications each season could supply bearing pear trees with adequate $\mathrm{N}$ and $\mathrm{P}$ nutrition without resulting in any reduction in soil indigenous $\mathrm{N}$ and $\mathrm{P}$ supply in the mid-Columbia region of Oregon. A shift from the broadcast application on the soil surface to split fertigation shows significant beneficial effects on reduction in fruit superficial scald, increase in fruit weight, and enhancement in $\mathrm{N}$ and $\mathrm{P}$ fertilizer use efficiency. Band placement of $\mathrm{N}$ and $\mathrm{P}$ increases fruit weight and reduces

Table 4. Effects of split fertigation and band placement of nitrogen $(\mathrm{N})$ and phosphorus $(\mathrm{P})$ on pear fruit superficial scald after 3-months of cold storage averaged over 2005 and 2006.

\begin{tabular}{|c|c|c|c|c|c|c|}
\hline Treatment $^{\mathrm{z}}$ & $\begin{array}{c}\text { Excellent } \\
(\%)\end{array}$ & $\begin{array}{c}\text { Very slightly } \\
\text { scalded (\%) }\end{array}$ & $\begin{array}{c}\text { Slightly } \\
\text { scalded (\%) }\end{array}$ & $\begin{array}{l}\text { Moderately } \\
\text { scalded (\%) }\end{array}$ & $\begin{array}{c}\text { Severely } \\
\text { scalded (\%) }\end{array}$ & $\begin{array}{c}\text { Marketable } \\
\text { fruit (\%) }\end{array}$ \\
\hline Broadcast & $20.4 \mathrm{c}^{\mathrm{y}}$ & $38.1 \mathrm{a}$ & 27.7 & 11.3 & 2.5 & $58.5 \mathrm{~b}$ \\
\hline Broadcast with soil disturbance & $37.4 \mathrm{a}$ & $26.4 \mathrm{~b}$ & 22.4 & 8.8 & 5.0 & $63.8 \mathrm{~b}$ \\
\hline Fertigation & $37.5 \mathrm{a}$ & $41.9 \mathrm{a}$ & 15.0 & 5.6 & 0.0 & $79.4 \mathrm{a}$ \\
\hline Significance $^{\mathrm{x}}$ & * & * & NS & NS & NS & * \\
\hline
\end{tabular}

${ }^{\mathrm{z}}$ Broadcast $=\mathrm{N}$ and $\mathrm{P}$ fertilizers were broadcast applied on the soil surface in a 10 - $\mathrm{ft}$-wide, weed-free strip centered on the tree row; Band $=\mathrm{N}$ and $\mathrm{P}$ were banded in $\mathrm{l} \times \mathrm{l}$ - $\mathrm{ft}$ ditches (width $\times$ depth) on both sides of tree rows; Broadcast with soil disturbance $=1 \times 1$-ft ditches were dug on both sides of the tree row using the band placement equipment, then the dug soil was completely returned to the ditch without any fertilizer being banded; after the soil disturbance was completed, $\mathrm{N}$ and $\mathrm{P}$ were broadcast applied on the soil surface in a 10 -ft-wide, weed-free strip centered on the tree row; Fertigation $=\mathrm{N}$ and $\mathrm{P}$ were fertigated in five split but equal applications throughout the growing season; $\mathrm{l} \mathrm{ft}=0.3048 \mathrm{~m}$

'Values in column followed by the same letter are not significantly different via Fisher's protected least significant difference test at $5 \%$ probability level.

${ }^{*}$ indicates the treatment effect is statistically significant at $5 \%$ probability level; nonsignificant effect is denoted by Ns. 
fruit superficial scald compared with broadcast application with soil disturbance caused by band placement. Overall, our results suggest that split fertigation and band placement of $\mathrm{N}$ and $\mathrm{P}$ can be used to replace broadcast application on the soil surface on pear orchards to reduce fruit superficial scald during cold storage and improve the use efficiency of applied $\mathrm{N}$ and $\mathrm{P}$ in the mid-Columbia region of Oregon. We expect split $\mathrm{N}$ and $\mathrm{P}$ fertigation practices will be increasingly used in commercial pear production to improve fruit storability and reduce fertilizer costs, fertilizer application costs, and water pollution in Oregon and the Pacific northwestern United States.

\section{Literature cited}

Combs, S.M. and M.V. Nathan. 1998. Soil organic matter, p. 53-58. In: J.R. Brown (ed.). Recommended chemical soil test procedures for the north central region. North Central Reg. Res. Publ. No. 221. Univ. Missouri, Columbia.

Crisosto, C.H., R.S. Johnson, and T. DeJong. 1997. Orchard factors affecting postharvest stone fruit quality. HortScience 32:820-823.

Dasberg, S., A. Bar-Akiva, S. Spazisky, and A. Cohen. 1988. Fertigation versus broadcasting in an orange grove. Fert. Res. 15:147-154.

Eckert, D.J. and J.W. Johnson. 1985. Phosphorus fertilization in no-tillage corn production. Agron. J. 77:789-792.

Edwards, J.H., R.R. Bruce, B.D. Horton, J.L. Chesness, and E.J. Wehunt. 1982. Soil cation and water distribution as affected by $\mathrm{NH}_{4} \mathrm{NO}_{3}$ applied through a drip irrigation system. J. Amer. Soc. Hort. Sci. 107:1142-1148.

Ericson, N.A. 1993. Quality and storability in relation to fertigation of apple trees cv. Summerred. Acta Hort. 326: $73-83$.

Frank, K., D. Beegle, and J. Denning. 1998. Phosphorus, p. 21-23. In: J.R. Brown (ed.). Recommended chemical soil test procedures for the north central region. North Central Reg. Res. Publ. No. 221. Univ. Missouri, Columbia.

Gavlak, R.G., D.A. Horneck, and R.O. Miller. 1994. Plant, soil and water reference methods for the western region. Western Reg. Ext. Publ. 125 Univ. Alaska, Fairbanks.

Hairston, J.E., W.F. Jones, P.K. McConnaughey, L.K. Marshall, and K.B. Gill. 1990. Tillage and fertilizer management effects on soybean growth and yield on three Mississippi soils. J. Production Agr. 3:317-323.

Hart, J., T. Righetti, B. Stevens, B. Stebbins, P. Lombard, D. Burkhart, and P. Van Buskirk. 1997. Pear fertilizer guideline. Ext. Serv. Publ. Multimedia Catalog Ser. No. FG 59-E. Oregon State University, Corvallis.

Haynes, R.J. 1985. Principles of fertilizer use for trickle irrigated crops. Fert. Res. 6:235-255.

Khan, S.A., R.L. Mulvaney, and R.G. Hoeft. 2001. A simple soil test for detecting sites that are nonresponsive to nitrogen fertilization. Soil Sci. Soc. Amer. J. 65:1751-1760.

Klein, I., A. Meimon, and D. Skedi. 1999. Drip nitrogen, phosphorus, and potassium fertigation of "Apadona" pear. J. Plant Nutr. 22:489-499.

Klein, I., I. Levin, B. Bar-Yosef, R. Assaf, and A. Berkovitz. 1989. Drip nitrogen fertigation of 'Starking Delicious' apple trees. Plant Soil 119:305-314.

Kuehl, R.O. 1994. Statistical principles of research design and analysis. Duxbury Press, Belmont, CA.

Lauer, D.A. 1988. Vertical distribution in soil of unincorprated surface-applied phosphorus under sprinkler irrigation. Soil Sci. Soc. Amer. J. 52:1685-1692.

Mehlich, A. 1984. Mehlich 3 soil test extractant: A modification of Mehlich 2. Commun. Soil Sci. Plant Anal. 15:14091416.

Neilsen, G.H., P. Parchomchuk, E.J. Hogue, W.D. Wolk, and O.L. Lau. 1994. Response of apple trees to fertiga- tion-induced soil acidification. Can. J. Plant Sci. 74:347-351.

O'Neil, M.K., B.R. Gardner, and R.L. Roth. 1979. Orthophosphoric acid as a phosphorus fertilizer in trickle irrigation. Soil Sci. Soc. Amer. J. 43:283-286.

Rauschkolb, R.S., D.E. Rolston, R.J. Miller, A.B. Carlton, and R.G. Burau. 1976. Phosphorus fertilization with drip irrigation. Soil Sci. Soc. Amer. J. 40:68-72.

Sanchez, E.E. and T.L. Righetti. 1990. Managing nitrogen in pears. Good Fruit Grower October:12-16.

Sanchez, E.E., T.L. Righetti, D. Sugar, and P.B. Lombard. 1990a. Seasonal differences, soil texture and uptake of newly absorbed nitrogen in field-grown pear trees. J. Hort. Sci. 65:395-400.

Sanchez, E.E., T.L. Righetti, D. Sugar, and P.B. Lombard. 1990b. Response of Comice pear trees to a postharvest urea spray. J. Hort. Sci. 65:541-546.

Sanchez, J.E., C.E. Edson, G.W. Bird, M.E. Whalon, T.C. Willson, R.R. Harwood, K. Kizilakaya, J.E. Nugent, W. Klein, A. Middleton, T.L. Loudon, D.R. Mutch, and J. Scrimger. 2003. Orchard floor and nitrogen management influences soil and water quality and tart cherry yields. J. Amer. Soc. Hort. Sci. 128:277-284.

Wander, I.W. 1947. Calcium and phosphorus penetration in an orchard. Proc. Amer. Soc. Hort. Sci. 49:1-6.

Watershed Professionals Network. 1999. Oregon watershed assessment manual. June 1999. Oregon Watershed Enhancement Board, Salem, OR.

Watson, M.E. and J.R. Brown. 1998. pH and lime requirement, p. 13-16. In: J.R. Brown (ed.). Recommended chemical soil test procedures for the north central region. North Central Reg. Res. Publ. No. 221. Univ. Missouri, Columbia.

Worley, R.E., J.W. Daniel, J.D. Dutcher, K.A. Harrison, and B.G. Mullinix. 1995. A long-term comparison of broadcast application versus drip fertigation of nitrogen for mature pecan trees. HortTechnology 5:43-47. 